\title{
ANALISIS PERMINTAAN KREDIT INVESTASI PADA BANK SWASTA NASIONAL DI JAWA TIMUR
}

\author{
Oleh: \\ Daryanti Ningsih \\ Alumni Fakultas Ekonomi Universitas Muhammadiyah Malang \\ E-mail/No.Hp: - /081333093776 \\ Idah Zuhroh \\ Fakultas Ekonomi Universitas Muhammadiyah Malang \\ E-mail/No.Hp: - /0341460021
}

\begin{abstract}
This research aims to know influence of mount rate of interest of investment credit and inflation to investment credit of demand in national state bank east java. In this research use sekunder data which have been publicated by Bank of Indonesia and use double linier regretion and using eviews program. The solution focused at growth of investment credit of demand in national state bank at east java. From the result analyse obtained that both of the variable used in this model, channelization investment credit still very base on level of rate of credit and inflation. For a while from test conducted by hypothesizing test obtained rate credit have effect significant to investment credit of demand in national state bank east java, inflation no have effect significant to investment credit of demand in national state bank at east java.
\end{abstract}

Keywords: investment credit, bank, and East Java

\section{PENDAHULUAN}

Penyaluran kredit bertujuan untuk meningkatkan nilai kekayaan bank dan bahkan melaju atau tidaknya perekonomian di negara Indonesia masih sangat bergantung pada kredit bank. Dalam hal ini pihak bank terus mengembangkan kompetensi di bidang kredit untuk menggalang pertumbuhan kredit yang berkesinambungan dan sekaligus menjalankan fungsinya sebagai intermediasi keuangan. Penyaluran kredit akan sangat membantu bagi dunia usaha. Keterkaitan antara dunia usaha dengan lembaga keuangan bank tidak bisa dilepaskan. Pihak bank akan menyalurkan kredit berupa kredit investasi dan modal kerja yang dibutuhkan oleh pihak dunia usaha.

Walaupun sempat terjadi penurunan terhadap alokasi kredit pada
Bank Swasta Nasional di Jawa Timur, namun pada tahun 2009 perlahan-lahan mengalami peningkatan. Hal ini seiring dengan meningkatnya poftofolio kredit.

Krisis ekonomi nasional saat ini sangat dirasakan oleh masyarakat, bahkan sampai saat ini yang bersifat multidimensional dapat melumpuhkan semua sektor, baik setor moneter dan sektor riil. Untuk mengatasi krisis tersebut berbagai kebijakan telah ditempuh oleh pemerintah seperti penurunan suku bunga dan mempertahankan inflasi, agar relatif rendah. Walau berbagai kebijakan telah dibuat, namun dampak perubahan positif belum begitu banyak mempengaruhi daya beli masyarakat.

Perubahan suku bunga yang telah disosialisasikan tersebut oleh berbagai lembaga pembiayaan bank dan non bank 
berpengaruh terhadap perubahan harga barang yang dikonsumsi oleh masyarakat, sejalan dengan tuntutan hidup yang lebih modern dan akibat kemajuan tehnologi informasi, kebutuhan masyarakat juga berubah. Berbagai aktivitas ekonomi dilakukan untuk dapat meningkatkan penghasilan.

Menurut (Mankiw:2003) secara teori tingkat bunga yang dibayarkan bank adalah tingkat bunga nominal yang merupakan penjumlahan tingkat bunga riil ditambah inflasi. Adanya kenaikan atau penurunan inflasi akan berdampak pada kenaikan atau penurunan tingkat bunga kredit.

Suku bunga dan dan inflasi menjadi dua faktor penting yang mempengaruhi aktivitas penyaluran kredit. Keduanya tidak hanya mendorong suku bunga kredit tetapi juga membuat risiko kredit macet menjadi lebih besar dan dalam kondisi seperti ini kegiatan kredit perbankan harus tetap berlangsung. Di lain sisi kontrol BI atas inflasi juga sangat terbatas, karena inflasi dipengaruhi oleh banyak faktor. Oleh karena itu, BI selalu melakukan perkiraan terhadap perkembangan perekonomian, khususnya terhadap kemungkinan tekanan inflasi.

Penurunan laju inflasi selama tahun 2000an memberikan ruang gerak dan ekspektasi pasar untuk menurunkan suku bunga SBI. Turunnya suku bunga SBI diharapkan dapat semakin mendorong aktivitas perekonomian melalui penurunan suku bunga kredit perbankan, khususnya kredit investasi. Akan tetapi, karena berbagai penyebab penurunan suku bunga ini belum sepenuhnya ditransmisikan dalam penurunan suku bunga kredit yang diharapkan mendorong investasi pada sektor riil.

Sementara itu, inflasi jawa timur sampai dengan akhir tahun 2008 diperkirakan lebih tinggi dari pada pencapaian inflasi tahun 2007 yang sebesar 5,93\%. Dan juga keneikan minyak dunia, krisis pangan dunia, meningkatnya permintaan barang dan jasa sejalan dengan meningkatnya pengeluaran pemerintah pusat/daerah dalam menghadapi pemilu dan pemilihan pilkada diberbagai daerah. Faktor distribusi barang serta ekspetasi inflasi masyarakat diperkirakan merupakan faktor-faktor yang berpotensi meningkatkan inflasi di Jawa Timur. Pergerakan inflasi tahun 2008 masih akan tetap disumbangkan oleh komoditas-komoditas bahan makanan terutama komoditas yang memiliki keterkaitan erat dengan harga energi minyak bumi.(kajian Ekonomi Regional Jawa Timur).

Bank Indonesia (BI) sebagai penentu kebijakan moneter langsung merespon laju inflasi yang sangat tinggi dengan menaikkan BI-Rate. Kondisi tersebut tentunya dapat berpengaruh pada system perbankan nasional karena BI-Rate sebagai tingkat bunga panduan kedepan tentunya akan direspon oleh sistem perbankan dengan melakukan penyesuaian terhadap tingkat bunga yang akan ditawarkan kepada nasabah. Kenaikan tingkat bunga perbankan tersebut, tentunya berdampak negative terhadap fungsi intermediasi yang mulai berpengaruh dan kenaikan kredit macet.

Suku bunga kredit yang di tawarkan oleh Bank Swasta Nasional Jawa Timur pada saat ini di anggap beberapa kalangan baik dari pelaku bisnis maupun pakar ekonomi belum optimal. Mereka menuntut agar Bank Indonesia selaku pengusaha moneter mempengaruhi suku bunga deposito dan suku bunga kredit berkaitan dengan turunya SBI agar dapat meningkatkan atau mengembangkan sektor riil lewat kegiatan investasinya.

Dengan berbagai langkah yang telah dilakukan Bank Indonesia, maka 
perekonomian pada tahun-tahun berikutnya diharapkan Bank Swasta Nasional -khususnya di Jawa Timurmengalami perkembangan yang positif. Kondisi perbankan pun diharapkan akan terus mengalami perkembangan yang lebih baik sehingga fungsi intermediasi perbankan dapat berjalan dengan baik. Bank Indonesia sendiri telah memperkirakan dengan membaiknya fungsi intermediasi ini, maka kredit yang disalurkan khususnya kredit investasi akan mencapai pertumbuhan yang cukup baik. Pertumbuhan penyaluran kredit investasi ini diharapkan akan memberikan kontribusi yang signifikan terhadap pertumbuhan ekonomi di Indonesia. Karena itulah diperlukan adanya kebijakan-kebijakan yang mendorong penyaluran kredit perbankan kepada masyarakat khususnya dunia usaha terutama melalui upaya mendorong penyaluran kredit di sektor Usaha Mikro, Kecil dan Menengah (UMKM).

Untuk melihat pengaruh tingkat suku bunga kredit dan inflasi terhadap permintaan kredit investasi pada bank swasta nasional di Jawa Timur, penulis tertarik untuk mengkaji seberapa besar pengaruh tingkat suku bunga kredit dan inflasi terhadap permintaan kredit investasi pada bank swasta nasional di Jawa Timur selama periode Juli 2006Agustus 2009.

Berdasarkan uraian diatas, maka penelitian ini bertujuan untuk mengetahui pengaruh tingkat suku bunga kredit dan inflasi terhadap permintaan kredit investasi pada bank swasta nasional di Jawa Timur periode Juli 2006 - Agustus 2009.

\section{TINJAUAN PUSTAKA}

Menurut Ryan Kiryanto, berdasarkan hasil pengamatan lembaga perbankan, permintaan kredit selalu berubah. Perubahan itu diakibatkan oleh perubahan suku bunga dari tahun ke tahun sebagai indikasi perubahan konsumtif, baik kebutuhan primer, sekunder maupun tersier. Perubahan pola konsumtif ini akan berdampak pada perubahan harga.

Menurut mankiw (2003:58) tingkat bunga menyesuaikan sampai jumlah perusahaan yang ingin menanamkan modal sama dengan jumlah rumah tangga yang ingin menabung. Dengan kata lain, jumlah dana pinjaman yang diminta melebihi jumalh yang ditawarkan.

Pendapat aliran keynes mengenai tingkat bunga ini dijelaskan melalui teori yang dikenal dengan liquidty preferences theory. Teori ini menjelaskan bahwa tingkat bunga menentukan akan banyak atau tidaknya permintaan akan dana liquid di masyarakat. Permintaan uang tersebut mempunyai hubungan yang negatif dengan tingkat bunga. Semakin tinggi tingkat bunga, semakin rendah jumlah keseimbangan uang riil yang diminta.

Dengan adanya kenaikan harga, hal ini akan menurunkan daya beli masyarakat. Melihat daya beli masyarakat menurun maka rumah tangga produksi menurunkan kapasitas produksinya karena penurunan daya beli. masyarakat akan menurunkan permintaan terhadap produk yang dihasilkannya sehingga kalau kapasitas produksi ditambah tentu akan merugikan. Penurunan kapasitas produksi dapat mengakibatkan penurunan permintaan kredit investasi oleh rumah tangga produksi.

Menurut Ni Nyoman Aryaningsih Perubahan harga dan perubahan laju inflasi yang relatif meningkat justru tidak menyurutkan keinginan masyarakat untuk mengikuti perkembangan pemenuhan kebutuhannya. Untuk dapat memenuhi segala kebutuhannya dilakukan usaha, agar dapat membantu 
menambah penghasilannya. Berbagai cara dilakukan masyarakat mulai dari investasi sederhana sampai dengan investasi bermodal besar. Dampaknya pada sektor moneter adalah permohonan modal usaha dan investasi akhinya semakin meningkat. Permohonan modal tersebut, mengarah kepada permohonan kredit ke lembaga perbankan yang semakin meningkat.

\section{METODE PENELITIAN}

Penelitian ini dilakukan pada Bank Swasta Nasional di Jawa Timur periode Juli 2006 - Agustus 2009. Data yang digunakan dalam penelitian ini merupakan data skunder, yang artinya data yang telah dikumpulkan dan diterbitkan oleh Bank Indonesia (BI), dan di publikasikan untuk masyarakat dalam bentuk dokumentasi yang di antaranya adalah data sebagai berikut: 1 . Tingkat permintaan kredit investasi pada Bank swasta nasional di Jawa Timur periode Juli 2006-Agustus 2009, 2. Tingkat suku bunga kredit investasi pada Bank swasta nasional di Jawa Timur periode Juli 2006-Agustus 2009, dan 3. Tingkat inflasi di Jawa Timur periode Juli 2006-Agustus 2009.

Adapun variabel yang digunakan dalam penelitian ini yaitu: Tingkat Permintaan Kredit Investasi, Tingkat Suku Bunga Kredit Investasi, dan Tingkat Inflasi. Sampel yang digunakan dalam penelitian ini ditentukan dengan menggunakan Bank-bank swasta GoPublic yang memberikan kredit investasi.

Untuk menjawab rumusan dan mengkaji hipotesis pada penelitian ini maka teknik analisis data yang di gunakan adalah Analisis Regresi Linier Berganda, Persamaan regresi linier berganda merupakan regresi lebih dari dua variabel, dimana regresi ini dilakukan atas satu variabel terikat (Y) terhadap lebih dari satu variabel terikat
(X). pada regresi linier berganda ini tujuannya untuk mengetahui pengaruh antara variabel bebas secara keseluruhan terhadap variabel terikat, dengan analisa menggunakan model persamaan kuadrat terkecil (metode OLS), dimana model regresi menurut panduan praktikum Statistik II UMM (2009) adalah sebagai berikut:

$\mathrm{Y}=\mathrm{a}+\mathrm{b}_{1} \mathrm{X}_{1}+\mathrm{b}_{2} \mathrm{X}_{2}+\mathrm{e}$

Dimana : Y: Permintaan Kredit Investasi; $\mathrm{X}_{1:}$ Suku Bunga Kredit Investasi; $\mathrm{X}_{2}$ : Tingkat Inflasi; e: Variabel pengganggu; a: Intersep; dan $b_{1}, b_{2}$ : koefisien regresi

\section{PEMBAHASAN}

Suku bunga merupakan sejumlah rupiah yang harus dibayar akibat telah mempergunakan dana sebagai balas jasa. Perubahan suku bunga merupakan perubahan dalam permintaan kredit. Kenaikan suku bunga akan mengakibatkan penurunan pengeluaran investasi. Dibawah ini merupakan perkembangan suku bunga kredit periode juli 2006- agustus 2009.

$$
\text { Untuk lebih jelasnya }
$$
perkembangan suku bunga kredit ini dapat dilihat pada gambar 1 .

Pada gambar 1, bahwa dari tahun 2006 sampai juli tahun 2009 suku bunga kredit cenderung menurun dikarenakan menurunnya $B I$ rate akibat dari menurunnya suku bunga global. Dengan menurunnya suku bunga kredit diharapkan dapat meningkatkan investasi dalam negeri. Dimana pada juli tahun 2006, suku bunga kredit sebesar 16,52\%, sedangkan pada bulan juni suku bunga kredit turun berada pada angka 12,34\% yaitu menurun sekitar $4,18 \%$ selama kurun waktu dua tahun. Dan pada juli 2008 sampai pertengahan tahun 2009 suku bunga kredit mengalami kenaikan hingga sekitar $1,6 \%$.

Inflasi merupakan perubahan harga yang cenderung meningkat, tanpa 
diimbangi perubahan daya beli masyarakat yang meningkat. Inflasi yang mampu diamati sebagai acuan untuk melakukan penelitian adalah inflasi yang diukur berdasarkan indeks harga yang dihitung perbulan berdasarkan

penelusuran harga yang mampu dibayar dalam satuan rupiah oleh produsen dan konsumen. Berikut merupakan perkembangan inflasi periode juli 2006agustus

2009

Tabel 1. Perkembangan suku bunga kredit investasi Juli 2006-agustus 2009

\begin{tabular}{|c|c|c|c|c|}
\hline Bulan & 2006 & 2007 & 2008 & 2009 \\
\hline Januari & - & 15.21 & 12.90 & 14.83 \\
\hline Februari & - & 14.98 & 12.76 & 14.72 \\
\hline Maret & - & 14.73 & 12.54 & 14.52 \\
\hline April & - & 14.46 & 12.39 & 14.58 \\
\hline Mei & - & 14.22 & 12.20 & 14.52 \\
\hline Juni & - & 14.04 & 12.34 & 14.33 \\
\hline Juli & 16.52 & 13.88 & 12.54 & 14.14 \\
\hline Agustus & 16.39 & 13.69 & 12.85 & 13.94 \\
\hline September & 16.13 & 13.49 & 13.48 & - \\
\hline Oktober & 15.99 & 13.37 & 14.21 & - \\
\hline Nopember & 15.75 & 13.26 & 14.61 & - \\
\hline Desember & 15.42 & 13.11 & 14.85 & - \\
\hline
\end{tabular}

Sumber: data triwulanan, BI Malang, 2009

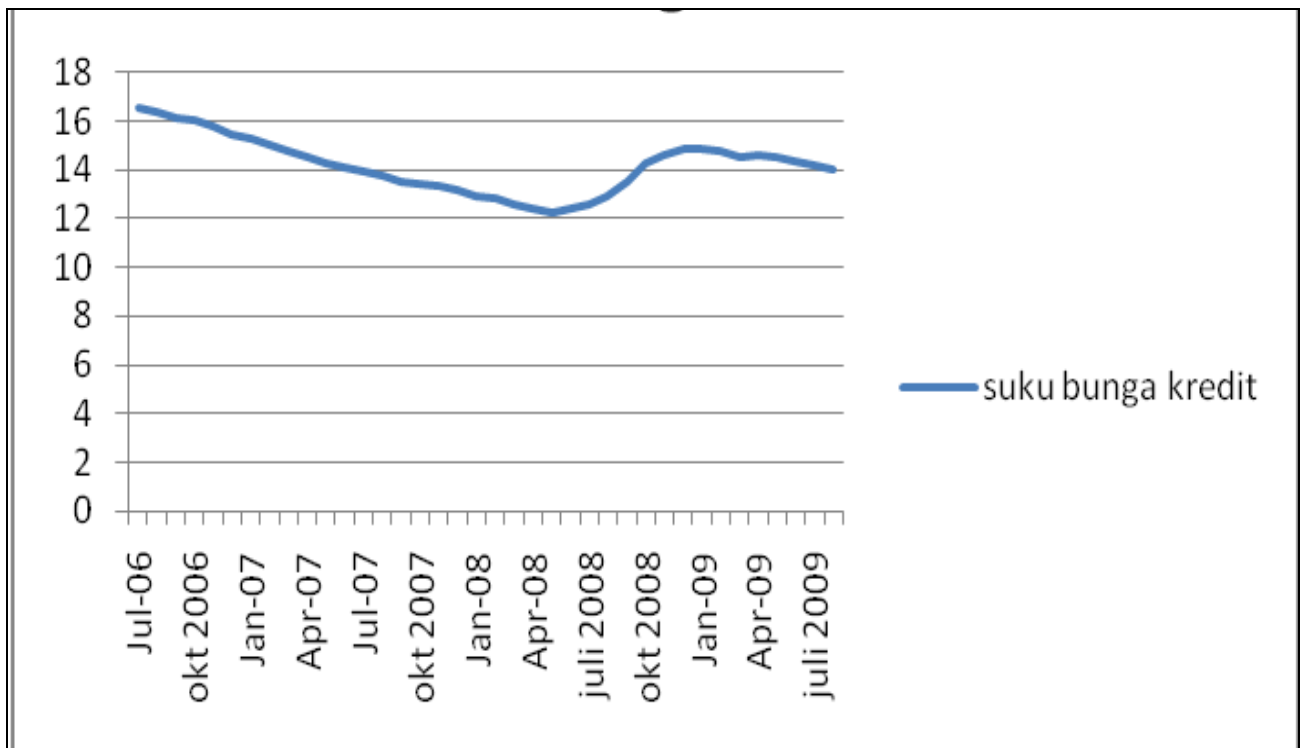

Gambar 1. Suku bunga kredit Juli 2006-Agustus 2009

Sumber: data triwulanan, BI Malang, diolah, 2009 
Tabel 2. Perkembangan inflasi Juli 2006-agustus 2009

\begin{tabular}{|c|c|c|c|c|}
\hline Bulan & 2006 & 2007 & 2008 & 2009 \\
\hline Januari & - & 6.26 & 7.36 & 9.17 \\
\hline Februari & - & 6.30 & 7.40 & 8.60 \\
\hline Maret & - & 6.52 & 8.17 & 7.92 \\
\hline April & - & 6.29 & 8.96 & 7.31 \\
\hline Mei & - & 6.01 & 10.38 & 6.04 \\
\hline Juni & - & 5.77 & 11.03 & 3.65 \\
\hline Juli & 15.15 & 6.06 & 11.90 & 2.71 \\
\hline Agustus & 14.90 & 6.51 & 11.85 & 2.75 \\
\hline September & 14.55 & 6.95 & 12.14 & - \\
\hline Oktober & 6.29 & 6.88 & 11.77 & - \\
\hline Nopember & 5.27 & 6.71 & 11.68 & - \\
\hline Desember & 6.60 & 6.59 & 11.06 & - \\
\hline
\end{tabular}

Sumber: data tahunan, BI Malang, 2009

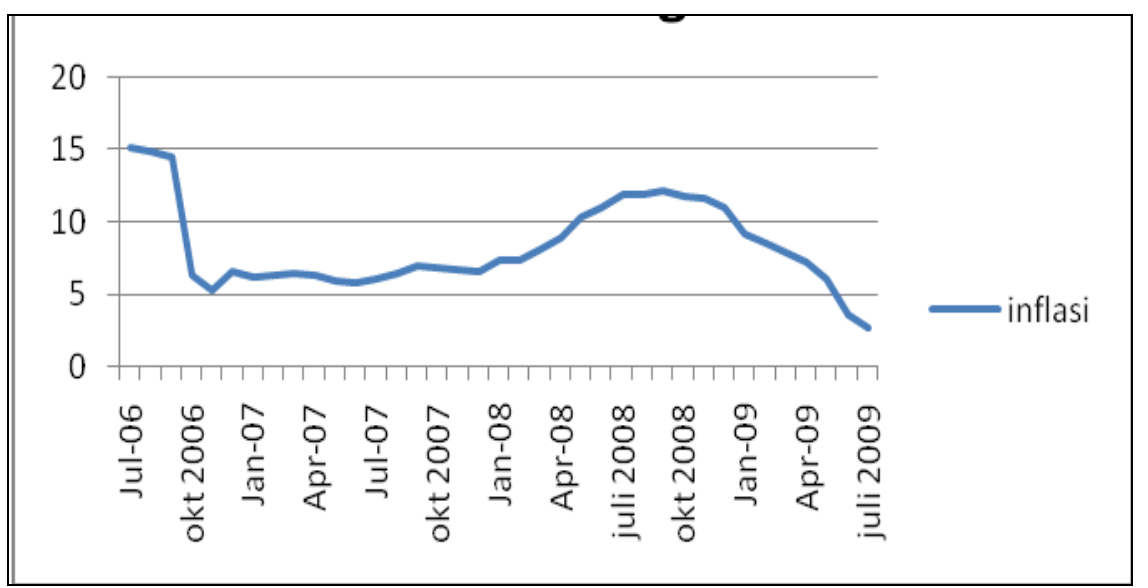

Gambar 2. Perkembangan Inflasi Juli 2006-Agustus 2009

Sumber: data tahunan, BI Malang, diolah, 2009

Tabel 3. Perkembangan permintaan kredit investasi bank swasta nasional di Jawa Timur Periode juli 2006-agustus 2009

\begin{tabular}{|c|c|c|c|c|}
\hline Bulan & 2006 & 2007 & 2008 & 2009 \\
\hline Januari & - & 3849.527 & 5673.798 & 6434.646 \\
\hline Februari & - & 3990.447 & 5673.798 & 6561.471 \\
\hline Maret & - & 3946.780 & 5691.780 & 6577.590 \\
\hline April & - & 4538.230 & 5872.478 & 6823.583 \\
\hline Mei & - & 4642.441 & 6054.359 & 6926.261 \\
\hline Juni & - & 4736.205 & 6140.758 & 7038.452 \\
\hline Juli & 3572.039 & 5720.450 & 6200.690 & 7157.829 \\
\hline Agustus & 3794.813 & 5957.818 & 6239.317 & 6889.575 \\
\hline September & 3865.356 & 5836.402 & 6297.785 & - \\
\hline Oktober & 3917.195 & 5985.454 & 6461.967 & - \\
\hline Nopember & 3915.247 & 6096.336 & 6494.274 & - \\
\hline Desember & 3865.514 & 6251.240 & 6525.034 & - \\
\hline
\end{tabular}

Sumber: data tahunan, BI Malang, 2009 
Berdasarkan tabel 3, bahwa sepanjang januari sampai november tahun 2008 inflasi mengalami kenaikan, pemicu utamanya harga komoditas terutama kelompok makanan yang terus meningkat secara signifikan. Fenomena meningkatnya harga komoditas makanan ini juga terjadi di beberapa negara lain. Di China misalnya, meningkatnya harga komoditas makanan telah mendorong inflasi selama Januari 2008 mencapai $7,1 \%$. Padahal selama tahun 2007, China hanya mengalami inflasi sekitar $4,8 \%$ dengan pertumbuhan ekonomi yang mencapai $11,4 \%$.

Perkembangan permintaan kredit investasi pada bank swasta nasional di jawa timur dapat dilihat di tabel 3 .

Berdasarkan tabel 3 dapat diketahui bahwa permintaan kredit bank swasta di jawa timur pada tahun 2006 sampai dengan agustus 2009 di kisaran 3 sampai 6 juta rupiah. Permintaan kredit ini mengalami kenaikan dari tahun ke tahun. Hal ini menggambarkan bahwa minat investasi terutama di jawa timur mulai membaik. Sehingga untuk lebih jelas arah perkembangan permintaan kredit investasi bank swasta di jawa timur dalam 1 bulanan dari tabel dapat dibuat gambar seperti gambar 3 .

Dari gambar 3, bahwa sepanjang tahun 2006 sampai 2009 permintaan kredit investasi bank swasta nasional di jawa timur mengalami kenaikan seiring dengan pertumbuhan sektor ekonomi di jawa timur dan mulai terealisasinya proyek-proyek pemerintah dan dunia usaha. Pada tahun 2006 permintaan kredit investasi bank swasta di jawa timur sebesar 3572.039 (dlm miliar rupiah) dan pada agustus 2009 permintaan kredit investasi bank swasta nasional di jawa timur menjadi 6889.575 (dlm miliar rupiah) yaitu naik sekitar 3317.536 (dlm miliar rupiah).
Pada penelitian ini analisis yang digunakan adalah analisis regresi berganda, ini digunakan untuk menghitung besarnya pengaruh antara variabel bebas yang terdiri dari variabel (Y) tingkat permintaan kredit investasi bank swasta nasional di jawa timur, varibel $\left(\mathrm{X}_{1}\right)$ suku bunga kredit dan variabel $\left(\mathrm{X}_{2}\right)$ inflasi.

Suku Bunga $\left(X_{1}\right)$, Pada saat suku bunga naik maka makin tinggi pula keinginan masyarakat untuk menabung. Artinya pada tingkat suku bunga yang lebih tinggi masyarakat terdorong untuk mengorbankan atau mengurangi pengeluaran untuk konsumsi guna menambah tabungan. Investasi juga merupakan fungsi dari tingkat suku bunga. Makin tinggi suku bunga, maka keinginan untuk melakukan investasi juga makin kecil, sebab tingkat pengembalian dan penggunaan dana juga makin besar. Di sektor perbankan, kondisi perbankan nasional secara umum relatif stabil, dan respons suku bunga perbankan terhadap penurunan BI Rate mulai membaik. Secara mikro, kondisi perbankan nasional stabil, yang diindikasikan oleh masih terjaganya rasio kecukupan modal (CAR) per Juni 2009 sebesar $17,0 \%$. Sementara itu rasio gross Non Performing Loan (NPL) tetap terkendali di bawah 5\% dengan rasio net di bawah 2\%. Likuiditas Perbankan, termasuk likuiditas dalam pasar uang antar bank makin membaik dan Dana Pihak Ketiga (DPK) meningkat. Sementara itu, penurunan BI Rate sebesar 250 bps selama tahun 2009 juga terus diikuti oleh penurunan suku bunga perbankan. Sejak dimulainya fase pelonggaran kebijakan moneter, suku bunga simpanan perbankan (deposito) telah mencatat penurunan sekitar 188 bps. 
Gambar 3. Permintaan Kredit Investasi Bank Swasta Nasional di Jawa Timur Juli 2006 - Agustus 2009

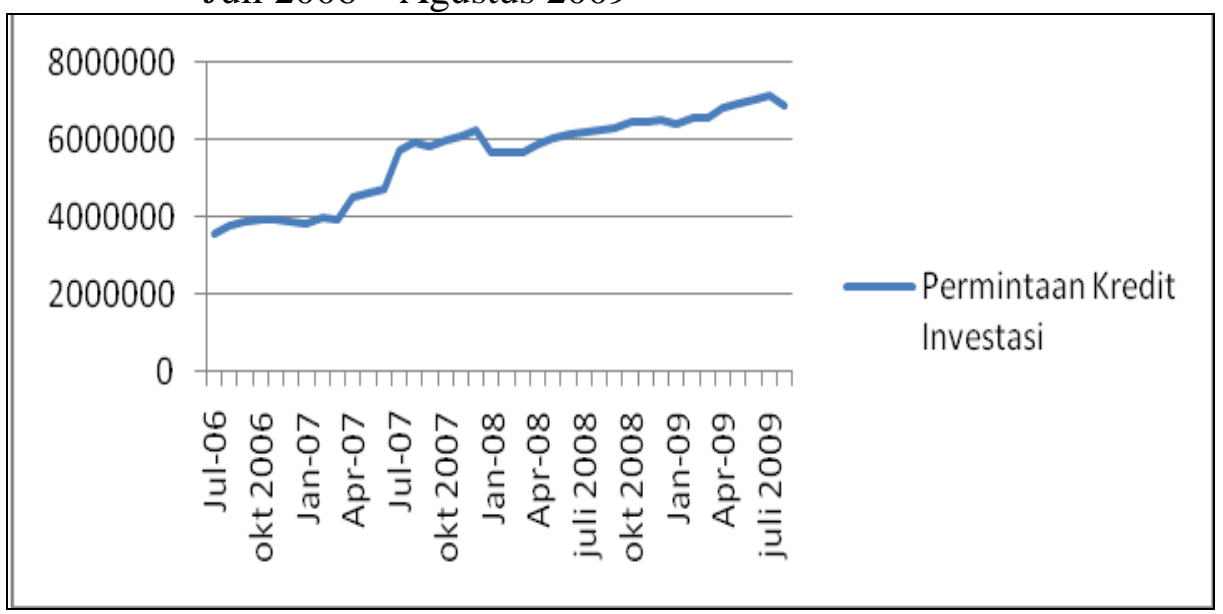

Sumber: data tahunan, BI Malang, diolah, 2009

Inflasi $\left(X_{2}\right)$, Inflasi berpengaruh terhadap permintaan kredit investasi, dikarenakan inflasi merupakan kenaikan harga. Semakin naiknya harga, maka seseorang akan berusaha untuk dapat memenuhi kebutuhan, dan dalam pemenuhan kebutuhan tersebut bisa dengan cara mengajukan permintaan kredit.oleh karena itu dengan adanya kenaikan inflasi maka permintaan kredit juga akan meningkat. laju inflasi pada periode 2009 ini relatif tinggi. Hal tersebut antara lain disebabkan oleh faktor musiman terkait dengan dimulainya tahun ajaran baru serta berakhirnya panen raya yang pada gilirannya mendorong tertahannya penurunan harga beras yang terjadi dalam beberapa bulan terakhir. Sementara itu, respon suku bunga kredit lebih terbatas yaitu sekitar 24 bps. Penyaluran kredit perbankan juga mulai menunjukkan perbaikan, walaupun masih tumbuh sangat lambat. Sampai dengan Juni 2009, kredit perbankan baru tumbuh sebesar 1,1\% (ytd). Masih terbatasnya penyaluran kredit antara lain terkait dengan masih tingginya persepsi risiko di sektor riil, sementara di sisi lain, permintaan kredit juga masih rendah terkait dengan masih rendahnya kegiatan investasi.

Dari hasil regresi (tabel 4) dapat disusun persamaan regresi sebagai berikut:

$$
\begin{aligned}
& \mathrm{Y}=13497.86-540.6745\left(\mathrm{X}_{1}\right)- \\
& 31.74564\left(\mathrm{X}_{2}\right)+\mathrm{ei}
\end{aligned}
$$
interprestasikan sebagai berikut:

$\beta_{0}=13497.86$; nilai permintaan kredit investasi bank swasta nasional di jawa timur akan sebesar 13497.86 pada saat suku bunga kredit dan inflasi sama dengan nol.

$\beta_{1}=-\quad 540.6745 ; \quad$ koefisien regresi variabel suku bunga kredit $\left(\mathrm{X}_{1}\right)$ akan sebesar -540.6745; berarti ada pengaruh negatif antara suku bunga kredit terhadap permintaan investasi bank swasta nasional di jawa timur. Apabila apabila nilai suku bunga kredit $\left(\mathrm{X}_{1}\right)$ naik sebesar satu satuan, maka permintaan kredit investasi bank swasta nasional di jawa timur (Y) akan turun sebesar - 540.6745. Sebaliknya, apabila nilai suku bunga kredit $\left(\mathrm{X}_{1}\right)$ turun sebesar satu satuan, maka permintaan kredit investasi bank swasta nasional di jawa timur akan naik sebesar 540.6745. Asumsi variabel yang lain tetap. 
Tabel 4. Hasil Uji Regresi Berganda

\begin{tabular}{|c|c|c|c|c|}
\hline $\begin{array}{l}\text { Dependent Variable } \\
\text { Method: Least Squa } \\
\text { Date: } 12 / 22 / 09 \text { Tim } \\
\text { Sample: } 2006: 0720 \\
\text { Included observation }\end{array}$ & $: 11$ & & & \\
\hline Variable & Coefficient & Std. Error & t-Statistic & Prob. \\
\hline $\mathrm{C}$ & 13497.86 & 1910.320 & 7.065762 & 0.0000 \\
\hline $\mathrm{X} 1$ & -540.6745 & 134.9966 & -4.005098 & 0.0003 \\
\hline $\mathrm{X} 2$ & -31.74564 & 50.20455 & -0.632326 & 0.5313 \\
\hline R-squared & 0.331261 & Mean deper & ent var & 5584.419 \\
\hline Adjusted R-squared & 0.293047 & S.D. depenc & ht var & 1133.233 \\
\hline S.E. of regression & 952.8276 & Akaike info & terion & 16.63240 \\
\hline Sum squared resid & 31775814 & Schwarz crit & & 16.76168 \\
\hline Log likelihood & -313.0156 & F-statistic & & 8.668658 \\
\hline Durbin-Watson stat & 0.085479 & Prob(F-stati & & 0.000875 \\
\hline
\end{tabular}

$$
\beta_{2}=-\quad 31.74564 ; \quad \text { koefisien }
$$
regresi variabel inflasi $\left(\mathrm{X}_{2}\right)$ akan sebesar - 31.74564; berarti ada pengaruh negatif antara investasi terhadap permintaan investasi bank swasta nasional di jawa timur. Apabila apabila nilai inflasi $\left(\mathrm{X}_{2}\right)$ naik sebesar satu satuan, maka permintaan kredit investasi bank swasta nasional di jawa timur (Y) akan turun sebesar - 31.74564. Sebaliknya, apabila nilai inflasi $\left(\mathrm{X}_{2}\right)$ turun sebesar satu satuan, maka permintaan kredit investasi bank swasta nasional di jawa timur akan naik sebesar - 31.74564. Asumsi variabel yang lain tetap.

Pengaruh secara parsial antara variabel suku bunga kredit terhadap permintaan kredit investasi bank swasta nasional di jawa timur adalah signifikan, pengaruh secara parsial antara variabel suku bunga kredit terhadap permintaan kredit investasi bank swasta nasional di jawa timur adalah tidak signifikan

Nilai F statistik dapat dilihat pada hasil regresi yaitu sebesar 8.668658, sedangkan dengan tingkat signifikan $\alpha=5 \%$ diperoleh $\mathrm{F}_{\text {table }}$ sebesar 3.23. Karena F hitung $>\mathrm{F}$ tabel (8.668658>3.23), maka Ho ditolak, artinya suku bunga kredit (\%) dan inflasi (\%) secara bersama-sama berpengaruh signifikan terhadap permintaan kredit investasi bank swasta nasional di jawa timur.

Berdasarkan regresi diatas diperoleh nilai $\mathrm{R}^{2}$ sebesar 0.331261 $(33,12 \%)$. Berarti kemampuan model yaitu variabel suku bunga kredit $\left(\mathrm{X}_{1}\right)$ dan inflasi $\left(\mathrm{X}_{2}\right)$ dalam menjelaskan variabel permintaan kredit investasi bank swasta nasional di jawa timur (Y) sebesar 33,12\%. Sedangkan sisanya sebesar $66.88 \%$ dijelaskan oleh variabel lain diluar model (variabel pengganggu/standar error).

Dari analisa yang dilakukan menunjukkan bahwa tidak sepenuhnya variabel suku bunga kredit investasi $\left(\mathrm{X}_{1}\right)$ dan inflasi $\left(\mathrm{X}_{2}\right)$ tidak sepenuhnya berpengaruh signifkan terhadap permintaan kredit investasi bank swasta nasional di jawa timur (Y). Adapun variabel-variabel tersebut akan dijelaskan sebagai berikut:

Suku Bunga Kredit Investasi, Pada estimasi regresi linier berganda menunjukkan bahwa suku bunga kredit investasi berpengaruh signifikan terhadap permintaan kredit investasi bank swasta nasional di jawa timur dengan tingkat signifikan $5 \%$ dengan nilai koefisien regresi sebesar -4.005098 . Variabel suku bunga kredit investasi ini berpengaruh negatif terhadap permintaan kredit investasi bank swasta nasional di 
jawa timur, sehingga hal tersebut sesuai dengan hipotesis bahwa apabila suku bunga kredit investasi mengalami kenaikan maka permintaan kredit investasi bank swasta nasional di jawa timur akan mengalami penurunan, dan ketika suku bunga kredit investasi menurun maka permintaan kredit investasi bank swasta nasional di jawa timur akan mengalami kenaikan. Dengan adanya penurunan suku bunga kredit akan menyebabkan bergairahnya dunia usaha, karena penurunan suku bunga kredit mempunyai sifatnya ekspansif terhadap sektor rill, maksudnya dengan suku bunga yang rendah maka dunia usaha cenderung akan memperbesar pinjamannya untuk memperluas investasinya. Ini dikarenakan biaya modalnya murah sedangkan bila suku bunga tinggi maka dunia usaha kesulitan mencari dana untuk membiayai proyek.

Inflasi, Dari hasil penelitian ini menunjukkan inflasi tidak berpengaruh secara signifikan karena perubahan laju inflasi yang relatif meningkat justru tidak menyurutkan keinginan masyarakat untuk mengajukan kredit kepada lembaga perbankan guna untuk menambah modal usaha. Inflasi merupakan kenaikan harga-harga barang dan jasa dalam periode tertentu. Bagi pelaku usaha kenaikan harga akan memacu untuk menjual lebih banyak barang, hal ini berarti memerlukan modal yang lebih besar dengan cara mencairkan kredit walaupun laju inflasi sangat tinggi. Tidak terpengaruhnya inflasi terhadap permintaan kredit investasi pada bank swasta nasional di jawa timur disebabkan karena betapapun tingginya inflasi jika mereka sangat membutuhkan modal maka akan mengajukan kredit pada perbankan tanpa harus terpengaruh oleh tinggi rendahnya tingkat inflasi.

Dari hasil penelitian ini menunjukkan bahwa tingkat inflasi berpengaruh negatif terhadap permintaan kredit investasi dengan koefisien regresi sebesar -31.74564 dan tidak signifikan pada tingkat signifikan 5\%.

\section{PENUTUP}

Berdasarkan hasil pengujian dan analisa hipotesa pada Bab IV, maka dapat ditarik kesimpulan dan saran sebagai berikut: Pertama, suku bunga kredit investasi mencapai koefisien 540.6745 yang berarti jika terjadi perubahan kenaikan satu poin suku bunga kredit investasi maka akan menurunkan permintaan kredit investasi bank swasta nasional di jawa timur 540.6745 .

Kedua, tingkat inflasi mencapai koefisien regresi -31.74564 yang berarti jika terjadi perubahan kenaikan satu poin tingkat inflasi maka akan menurunkan permintaan kredit investasi -31.74564.

Ketiga, permintaan kredit investasi bank swasta nasional di jawa timur akan sebesar 13497.86 jika pada saat itu suku bunga kredit investasi $\left(\mathrm{X}_{1}\right)$ dan tingkat inflasi $\left(\mathrm{X}_{2}\right)$, sama dengan nol (konstan).

Dari hasil penelitian dan kesimpulan yang telah diperoleh, maka peneliti memberi saran: Pertama, Pemerintah diharapkan dapat melakukan suatu tindakan untuk menurunkan tingkat suku bunga kredit investasi dan inflasi sehingga akan mendorong peningkatan investasi di Indonesia dan dapat meminimalisir risiko penyaluran kredit ke dunia usaha.

Kedua, Bagi para pelaku usaha disarankan sedapat mungkin mengetahui informasi mengenai suku bunga kredit dan tingkat inflasi yang terjadi sehingga pelaku usaha dapat mengetahui tentang keadaan perekonomian di Indonesia. Dan juga dapat membantu pemerintah agar risiko penyaluran kredit dapat ditekan. 
Bagi penelitian selanjutnya karena keterbatasan dalam penelitian pengaruh suku bunga kredit investasi dan inflasi terhadap permintaan kredit investasi bank swasta nasional di jawa timur, Sehingga dapat diteliti juga faktor suku bunga kredit dan inflasi luar negeri (Amerika), nilai tukar rupiah dan tingkat perekonomian Indonesia.

\section{DAFTAR PUSTAKA}

Boediono, Ekonomi Moneter, 1996, BPFE, Yogyakarta

Judiseno Rimsky K, Sistem Moneter dan Perbankan Indonesia, 2002, PT. Gramedia Pustaka Utama, Jakarta

Mankiw N. Gregory, Principle Of Economics, 2002, $3^{\text {th }}$ edition, terjemahan Chriswan Sungkono, Salemba Empat

Nopirin, 1992, Ekonomi Moneter, BPFE, Yogyakarta

Pudjo Muljo Teguh, 1989, Manajemen Perkreditan bagi Bank Komersil, BPFE, Yogyakarta

Rohmelawati, 2009, Analisis Tingkat Permintaan Kredit Investasi Pada Bank Umum di Wilayah Kerja Bank Indonesia Malang, UMM

Sutedjo Siswanto, 2007, Strategi Manajemen Kredit Bank Umum, Damar Mulya Pustaka, Jakarta

Thomas Suyatno, 2003, Kelembagaan Perbankan, PT. Gramedia Pustaka Utama, Anggota IKPI, Jakarta

Widayat, 2004, Metode Penelitian Pemasaran, CV. Cahaya Press, Malang
Http://depkeu.go.id, Diakses tanggal 10 Agustus 2009

Http:// bi.go.id, Diakses tanggal 10 Agustus 2009

Http:// bi.go.id, Diakses tanggal 25 Januari 2010

Http:// surabayapost.co.id, Diakses tanggal 10 Agustus 2009 
